University of New Orleans

ScholarWorks@UNO

1991

\title{
The American Generational Autobiography: Malcolm Cowley and Michael Rossman
}

John D. Hazlett

University of New Orleans, jhazlett@uno.edu

Follow this and additional works at: https://scholarworks.uno.edu/engl_facpubs

Part of the Literature in English, North America Commons

\section{Recommended Citation}

Hazlett, John D. "The American Generational Autobiography: Malcolm Cowley and Michael Rossman," Prospects: An Annual Journal of American Cultural Studies, Vol. 16., ed. Jack Salzman (New York: Cambridge UP, 1991), pp. 421-442.

This Article is brought to you for free and open access by the Department of English and Foreign Languages at ScholarWorks@UNO. It has been accepted for inclusion in English Faculty Publications by an authorized administrator of ScholarWorks@UNO.For more information, please contact scholarworks@uno.edu. 


\section{The American Generational Autobiography: Malcolm Cowley and Michael Rossman}

JOHN DOWNTON HAZLETT

$I^{\mathrm{N}}$ N THE PROLOGUE to his 1951 revision of Exile's Return, Malcolm Cowley generation" written "while its adition of 1934 as "the story of the lost He then added, "since I had shared in many of the adventures I planned tell a little of my own story, but only as an illustration of what had happened to others." In fact, this modest description of his method drastically understates the importance of Cowley's own life in the original story. In the first edition, he does combine stretches of narrative about his own life - including chapters on his childhood, high-school and college years, exile in Europe, disillusionment with bohemian life, and political conversion - with a narrative of the generation's coming of age. But even the story of the collective self that he means to tell - beginning with their early innocence in a pastoral, Edenic America; continuing through their exile and refuge in the religion of art and the subculture of bohemianism; and ending with their final repatriation and salvation via the political and historical insights of Marxism - is in every important respect simply his own writ large. It is a story in which the personal, individualized "I" of conventional autobiography is transformed into a collective "we."

Because of this peculiar blend of autobiography and collective history, classifying this book has always struck me as an intriguing task. In the past, critics wanting to dispose of the issue of the book's genre have often done so by calling it a literary memoir or a literary history. The publishers of the Viking Compass edition of 1956 have listed it simply as biography. These generic choices were made somewhat easier and more accurate by Cowley's 1951 revisions, which deleted a good bit of "his story" as well as the first edition's enthusiastic Marxism, neither of which seemed necessary in the politically paranoid atmosphere of the early $1950 \mathrm{~s} .{ }^{2}$ But each of these choices also made it easier to ignore what Cowley was really 


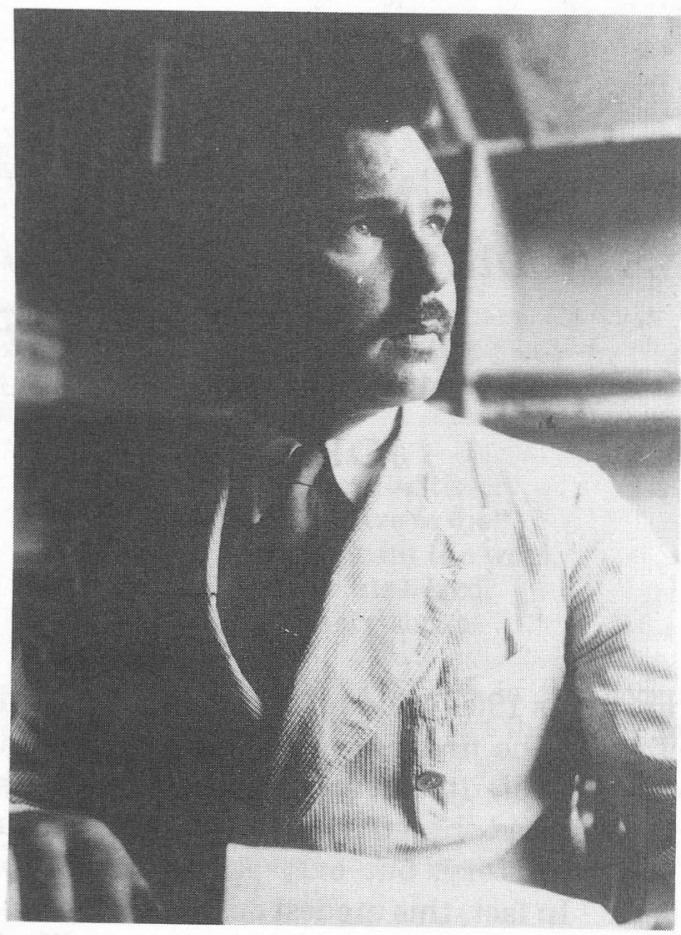

Figure 1. Malcolm Cowley in 1934, the year in which Exile's Return was first published. Photo by Morton Dauwen Zabel.

trying to do in his 1934 book - to construct his own collective identity by narrating his generation's coming of age.

One reason that the book has not been read carefully as autobiography has to do with the kinds of assumptions that critics have long been making about the genre. Ever since Georges Gusdorf, one of the fathers of modern autobiographical theory, wrote his seminal essay "Conditions et limites de l'autobiographie" in 1956, historians of the genre have agreed that its ascendancy at the end of the 18th Century coincided with two developments that have marked the character of the modern age. The first of those developments was the emergence of the concept of a unique, interior, individual self; the second was the emergence of the modern concept of secular history. ${ }^{3}$ Romanticism's eventual apotheosis of the individual self in Western culture has been seen by some critics as an essential characteristic of modern autobiography. Others, following their lead, have also posited an inherent tie between this individualized self and the ideology of capitalism. ${ }^{4}$ Even when critics do not go so far as to claim such a linkage as inherent to the genre, their assumption that individuality is a dominant characteristic of autobiography plays a determining role in 
the kinds of works that are highlighted in the process of canon formation. Works that do not focus on the individual self tend to be ignored.

In reaction against this critical tendency, feminists and AfricanAmerican critics have pointed out that autobiographies by women and blacks very frequently do not highlight individuality, but instead focus on the way in which identity for members of these groups emerges out of collective processes, both as a response to a negative identity imposed upon them by a dominant cultural group and as the self-interested construction of a positive collective identity. An examination of such autobiographies reveals a number of characteristics at variance with the assumptions of prevailing theories of autobiography. First, they reveal that individuality need not be the central feature of the self constructed by the modern autobiographer. Second, they show that, for members of marginalized groups, collective identity is particularly important and often overshadows an author's unique identity. Third, they show that autobiographers may use the genre for political purposes at odds with the hegemonic ideology of the dominant culture. ${ }^{5}$

In the context of such collectively oriented autobiographies, Cowley's book is not entirely out of place. Cowley and his group of largely white male writers perceived themselves as members of a generation at odds with the dominant culture. As members of a new literary coterie within that generation, they also saw themselves as outside of the literary establishment. Cowley's project in Exile's Return, therefore, is to assert that his group is more representative of the generation than other groups are, and thereby to control the rhetoric by which the generation's identity would be constructed and to assure the group's access to the literary canon. Although his book also contains an explicit political intention (to facilitate the advent of a proletarian revolution), this intention seems to me secondary to his desire to gain access to cultural power for his own group. If the revolution is successful, Cowley wants his group to have power within it. If it is not, he wants his group to be in a position of power in relation to the bourgeois literary tradition.

Nor is Cowley's book by any means unique. Although not many of its kind were produced by the "lost generation" of the $1920 \mathrm{~s},{ }^{6}$ the general characteristics that he established for the "generational autobiography" (as I will call it here) are common in works written by the self-appointed autobiographers of the generation that came of age during the $1960 \mathrm{~s}$. Like their counterparts in the generation of the 1920 s, they perceived themselves as "different" from the generation of Americans that immediately preceded them and they were highly conscious of themselves as a generation. But for this later group, again largely comprised of young white men, access to the literary establishment was not a central concern. They were more directly interested in the distribution and use of political power throughout society. Their own marginalization, they thought, resulted both from their choice not to align themselves with corrupt power and from 
their status as youth. One of the best examples of generational autobiography from this later group, Michael Rossman's The Wedding Within the War (1971), asserts their identification with other marginalized groups and promises the construction of a collective identity for youth:

Students, and youth in general, are becoming aware of themselves as a class. Like the black people, they are coming to see themselves as a class exploited and oppressed - forced by outside interests of power and money to labor on the colonial plantation of the campus, in preparation for their roles in service to the technological economy of capitalism. Like the black people, they are learning to recognize brothers and band together. And like the blacks again, they are developing an independent cultural identity, and moving to build in their own self-interest. ${ }^{7}$

But although there are differences in the ways that Cowley and the later group construct their collective autobiographies, enough similarities exist to constitute an autobiographical mode that runs counter to the conventional autobiographical tradition.

Cowley's and Rossman's books both work within and against traditional notions of the genre in order to produce forms of collective autobiography. Cowley's text, as a prototype of 20th-Century American generational autobiographies, is most conspicuous for a feature that theorists such as Gusdorf would find paradoxical - the collective nature of the autobiographer's self. Apart from that divergence from convention, however, Cowley's text follows a narrative pattern that is familiar to readers of conventional autobiographies of conversion. Rossman's text too is structured around a collective self, but his notion of how that self is constructed differs from Cowley's, as does his notion of how the collective self should be presented narratively. Rossman's commitment to a dynamically evolving collective self, his greater emphasis on the prophetic role of the autobiographer, and the self-conscious use of identity politics contribute to some of the differences between his text and Cowley's.

For the structure of Exile's Return, Cowley made use of the narrative pattern and retrospective perspective suggested by his own conversion to Marxism in the early 1930s. The result was a conversion narrative in which an entire age cohort collectively sees the error of its capitalist and individualist ways. The crash of 1929 serves as their blinding light on the road to Damascus, and they turn to Marxist economics and the collectivist ideology of Soviet Russia for rebirth and a new identity. However, in order to construct a collective identity that could actually be said to follow this "plot" of the self, Cowley relies upon a combination of three culture theories. Marxism, which also provides the "faith" behind the conversion pattern of Cowley's narrative, is the most conspicuous of these theories. The other two are generationalism and Emersonian organicism. Each of them concerns itself with a distinct collective identity: generationalism 
with the generation, Emersonianism with the nation, and Marxism with the class. By means of these three theories of collective identity and historical process, Cowley is able to place the narrative of his generation's "conversion" within an historical context that spans at least the entire previous century. He succeeds, in other words, not only in making his individual experience stand for the identity of his entire generation, but also in making that generational identity equivalent to (because it recapitulates) national and class identities.

Although Cowley does not mention earlier generational writers in the first edition of his collective autobiography, he clearly was familiar with them. The generational idea was pervasive in the first three decades of the 20th Century, both in Europe and the United States, and it had a tremendous impact on the way in which young people saw themselves and their role in history. ${ }^{8}$ Robert Wohl, in an influential study of generationalism during this period, writes:

The nineteenth century tradition of the young generation as a vanguard of cultural and political change, the emergence of youth as a clearly defined and demographically significant social group, its organization, and a growing sense of collective historical destiny all converged to create a formidable wave of generational thinking during the first few decades of the twentieth century. This swell of generationalism reached its peak between 1928 and 1933, then slowly ebbed leaving its main traces in literature and memoirs. But during the years of flow the generational idea appeared on the pens and lips of men and women of all camps and countries. All these people were struck ... by the discovery that one's generation was a destiny whose iron shackles permitted no escape. ${ }^{9}$

Cowley himself was probably most influenced by Randolph Bourne, an American who formulated a generational theory between 1914 and 1919 , and José Ortega y Gasset, the Spanish philosopher whose main work on the generational theme was completed between 1920 and $1933 .{ }^{10}$ The idea that Cowley borrowed from Bourne, the hallmark of all of his later books on the writers who came of age during the $1920 \mathrm{~s}$, is that a generation's experiences in its youth. "A man's spiritual fabric," Bourne wrote, "is woven by that time." 11 Cowley echoes this idea when he explains in his prologue what set his generation apart from its predecessor: "They [his peers] came to maturity during a period of violent change, when the influence of time seemed temporarily more important than that of class or locality" (p. 7). ${ }^{12}$

Cowley's reliance on aspects of the generational theory of Ortega y Gasset for his notions of collective identity is apparent not only from explicit comments made in later works, ${ }^{13}$ but also from the way in which 
his opening discussion of generational character echoes Ortega's language. Ortega wrote that members of each generation enter the historical arena "endowed with certain typical characteristics which lend them a common physiognomy, distinguishing them from the previous generation." 14 Cowley, clearly responsive to the idea of generational identity, was eager to portray those things that made his own generation unique, particularly its habits of thought. In the prologue to the book, he catalogues those events and social changes that had served to separate his own generation from the previous one and to mark it more strongly as a generation than other age groups had been. Earlier Americans, he says, had identified themselves regionally or by class, but those who came of age between 1915 and 1925 were marked by history, by time. Momentous historical events and processes - the Great War, increased social mobility, urbanization, centralization and standardization of culture, education, language - affected his peers with such rapidity and finality that they were snatched forever out of the 19th-Century world that remained their parents' spiritual home. All of these factors helped to determine the collective identity of Cowley and his peers.

Cowley was also attracted to notions of a generational elite that appeared in both Bourne and Ortega. For Bourne, the generational elite was comprised of those individuals who lived most fully in consonance with the spirit of their times and therefore were the only people who were "actually contemporaneous" (Youth and Life, pp. 12-13). It was these young politicos who interpreted the "tasks" assigned to each generation by the spirit of the age. Ortega similarly claimed that the generation is made up of a mass and an elite. The expression of a generation's sensibility and destiny - its voice - is to be found among those "who are under the obligation, by reason of their eminent intellectual qualities, of assuming responsibility for the conduct of the age" (The Modern Theme, p. 21). Cowley's elite, by contrast, is artistic, consisting of people who could, in their own personalities and work, reflect the mood and style of their generation. The metaphor he uses for their role, a barometer, is particularly apt (p. 13). As "instruments" that were sensitive to (though often unconscious of) cultural and historical pressures, these generational representatives were more likely to behave in extreme ways than the mass of their contemporaries. Indeed, the extremity of their actions was often, according to writers like Cowley, the best indicator of the real condition of an outwardly prosperous and happy nation.

It was, in fact, this division of the generation into an elite and a mass that allowed autobiographers such as Cowley to write in the collective voice even though they relied for their narrative pattern largely on their own individual experiences. By identifying with the elite (perceived either as a barometer or as a political or cultural vanguard), generational autobiographers grant themselves the right to employ the plural firstperson pronoun. Their private and public lives stand in for the collective experience. What happens to "me" represents what happens to "us." 
Cowley's generationalism also differed from Bourne's and Ortega's in another way. Bourne and Ortega saw in generationalism not only a theory of collective identity, but also an explanation of history based on cycles of generational conflict and acquiescence. Cowley, by contrast, was primarily interested in generationalism for what it had to say about collective identity. When it came to telling the generation's story and to establishing an historical context within which his collective conversion narrative would make sense, Cowley turned to two other forms of historical and cultural analysis.

The first of these was the Emersonian critique of the disjunctions within American culture - idealism set against pragmatism, highbrow against lowbrow, genteel culture against materialism, an idealized Europe against a depreciated America. According to the Emersonians, America continued its cultural dependence upon England long after it had gained its political independence. Self-conscious about America's weak cultural identity and the lack of recognition afforded to native talents, Emerson and other cultural nationalists of the early decades of the 19th Century called for an indigenous culture, but almost every important writer in the century seriously considered some form of cultural "exile" as an alternative to reforming America. To leave America meant that one could make use of the cultural heritage of Europe and work within a society that was sympathetic to artists. But it also meant cutting oneself off from the wellsprings of artistic inspiration - one's homeland and childhood. To many artists, however, such exile was preferable to living in a society that was still so manifestly given to genteel (that is, class-based, acquisition-oriented) notions of culture. This struggle over American cultural identity and the dilemma facing its artists was fully elaborated in the years between 1890 and 1920 by Emersonians such as Thorstein Veblen, Van Wyck Brooks, and Randolph Bourne, each of whom called for the building of an organic, indigenous American cultural identity.

These decades were also the period when Cowley and his peers were coming of age, but the debate over American culture was not yet part of the American high-school or university curriculum. For all their education had taught them, the members of this generation still saw culture as the stuff that was produced by artists in Europe; in Cowley's words, "we never guessed that culture was the outgrowth of a situation" (p. 35). This ignorance placed his peers in the unfortunate position of having to repeat an entire century of national cultural history in their own lives. But it also allowed the older Cowley, from whose Emersonian point of view the autobiography is narrated, to place his own and his generation's search for identity in the larger framework of the national search for identity. The first section, "Mansions in the Air," for example, narrates the generation's childhood, during which Cowley and his peers were forced into their first spiritual exile through a "long process of deracination," which he blames on an official culture that relied too heavily upon European models. Cowley's account of his high-school and university experience is informed by a 
critique of the educational system that closely echoes the Emersonians' complaints. ${ }^{15}$ Later, in the middle sections of the book, the story of the generation's physical exile in Europe during the early 1920s represents a repetition of the exodus of 19th-Century American artists and a confirmation of the Emersonian critique. The story of his own and his generation's coming of age is, in short, a recapitulation of the nation's collective childhood and coming of age as narrated by Emersonian culture critics.

By relying on this tradition, Cowley for the first time endows the phrase "the lost generation" with more than a vaguely romantic value. By establishing this tradition, he shows that his generation not only "had special characteristics," but also that those characteristics were intimately related to national identity. In Cowley's collective autobiography, "the lost generation" for the first time connotes an entire critique of American history and culture. His generation was "lost" because it had been "schooled away" from an organic connection with America. Its culture, such as it was, was borrowed from Europe. Its rural and small-town roots had been destroyed by an urbanization that proceeded without regard for ethnic or local identities. Cowley's narration of the generation's movement from this state of cultural exile to repatriation is, therefore, partially the story of its movement toward the rediscovery of American Emersonianism and cultural nationalism.

I say "partially" because, by the time Cowley's collective self began to reclaim America in the 1930s, it was with the sense that the Emersonians alone could not save either America or Cowley's generation from the downward spiral of cultural decadence and economic exploitation that had culminated in the Great Depression. For this task, Cowley blended his Emersonian analysis with a Marxist one. The two traditions mixed well. The Emersonian romanticization of the common laborer and his culture complemented the Marxist glorification of the proletariat; the Emersonian struggle against an "inorganic" culture merged with the Marxist notion of the alienation of the laborer from the products of his labor. In the very midst of Cowley's discussion of his generation's deracination, for example, he concludes his Emersonian argument by stating that "our whole training was involuntarily directed... toward making us homeless citizens, not so much of the world as of international capitalism" (p. 29). Emersonians espoused the development of a national consciousness that would recognize that an "artisan knowing his tools and having the feel of his materials" (p. 35) was an example of true culture. Like Emersonians, the American Marxists found their examples of virtue and "real" culture in ordinary people, the workers, the farmers in their fields. Emersonians also criticized the simple-minded individualism that had created the American businessman whose ideals were conquest and "millionairism." Marxists criticized the social inequities resulting from the capitalist economy's reliance upon individualism and private competition. Marxists may have been more concerned than Emersonians with economic questions, and Marxism's European proponents may have been more convinced of the necessity of violent 
revolution to accomplish their aims, but by the time Cowley and his comrades in the League of Professional Groups (founded in 1932 to support the Communist Party ticket) began their fellow-traveling, they hoped that communism would establish a new culture, based upon principles that were, in large part, Emersonian.

Cowley's Marxism also gave another dimension to the idea of "the lost generation." American Marxists saw the 1920s as the last years of a dying capitalist culture. The bourgeois generation that came of age in those years was, according to Marxist prophecy, the last generation of an economic and political era that had lasted at least two hundred years. That middle-class literary generation's own "degeneration" in the 1920s, which is covered in the final third of the narrative, represented, therefore, the final death throes of the bourgeois class. As Cowley says in his prologue, "the story of the Lost Generation and its return from exile is... partly the story of a whole social class, how it became aware of itself and how it went marching toward the end of an era" (p. 13).

Cowley works this death out narratively in two sections of the book's final chapter (pp. 242-88) where he turns the narrative's attention away from himself and treats the suicide of his contemporary Harry Crosby, a minor poet whose life epitomized the generational trajectory that Cowley has been tracing. In Cowley's words, Crosby's life had a "quality that gave it logic and made it resemble a clear syllogism" (p. 265). Crosby's "brief and not particularly distinguished literary life of seven years," writes Cowley,

included practically all of the themes I have been trying to develop - the separation from home, the effects of service in the ambulance corps, the exile in France, then other themes, bohemianism, the religion of art, the escape from society, the effort to defend one's individuality even at the cost of sterility and madness, then the final period of demoralization when the whole philosophical structure crumbled from within, just at the moment when bourgeois society was beginning to crumble after its greatest outpouring of luxuries, its longest debauch - all this is suggested in Harry Crosby's life. (p. 243)

Crosby's suicide is portrayed, then, as a symbol of "the decay from within and the suicide of a whole order with which he had been identified" ( $p$. 284). Perhaps more importantly - since this is after all a conversion narrative - Crosby serves as the sacrificial goat whose death is required by the narrative form before the final Marxist rebirth of the author's collective identity can take place. Only through such a death of its unregenerate self was the generation able to emerge in the 1930 s with a new identity, regenerated and purified.

The way in which Crosby stands in for Cowley at this point exemplifies the way in which identity works in the narrative. What interests 
Cowley is not individuality, but typicality, so that one character can easily substitute for another or for the entire generation in his reconstruction of collective identity. The narrated pattern of Crosby's life is almost identical to Cowley's own up to 1929, the year that Cowley sees as the turning point for his generation. There are other, rather uncanny, substitutions at work in the fluid boundaries between egos as well. Besides the "themes" just quoted, Crosby and Cowley also had in common the same birth year, 1898; and surely the alliteration and assonance of their names would not have been lost on a poet like Cowley. Cowley's later selfcriticism (in his 1951 revision) that his account of Crosby's suicide allowed him unconsciously to avoid dealing with the suicide of another "HC," Hart Crane, a man to whom Cowley was very closely attached, only reinforces the point that identity boundaries in this work are fluid. ${ }^{16}$

By means of the collective death symbolized in the Crosby suicide, Cowley's generation became the first, in his view, to experience a rebirth into a Marxist future. The historic task of this collective "New Adam" was to help construct the promised land of the new proletarian age. But they would also be the first to actualize the aspirations of the older Emersonian writers. By the time Cowley finally spells out the details of his new Marxist "faith" in the book's epilogue, a perceptive reader will have already seen that the Genteel Tradition, which the Emersonians had been combating, has become identified in Cowley's hybrid ideology with Bourgeois-Capitalist Culture; and the Organic Culture promoted by the Emersonians has become one and the same with the new, ascendant Proletarian Culture.

During the period between 1960 and 1975, another generation came of age that was, in many ways, comparable to Cowley's. There are, of course, differences between the two groups. The most notable is that the generation that came of age during the 1920s did so during a period of political conservatism when the American left was largely ignored by the young. The 1960s were characterized by precisely the opposite kind of political attitude. Likewise, political attitudes among Cowley's peers changed in the 1930s from a politically conservative quietism to a leftist activism. ${ }^{17}$ For the later generation, a change in the opposite political direction was made as the group entered the decade of the 1970s. In spite of these differences, however, both generations were powerfully conscious of themselves as generations, and individual members of both groups felt that their membership in the generation was a determining factor in their
identities.

Many of the autobiographies written by members of the later generation were, like Cowley's, attempts to define the collective generational 
self and to narrate those experiences that had contributed most to its development. ${ }^{18}$ However, as producers of autobiographies specifically concerned with generational identity, the later group was much more prolific than Cowley's, partly because it came of age during a decade when many marginalized groups were intensely engaged in what is now called identity politics, ${ }^{19}$ an engagement that produced dozens of autobiographical works by women, blacks, gays, and chicanos. Since generational autobiographies from this period were "weapons" in precisely this sort of struggle, one of their most conspicuous qualities is their dialogical nature. Indeed, I would argue that they can only be properly understood when read in conjunction with one another, as so many voices in a dialogue about generational experience and identity. Such an argument may appear to detract from their value as individual texts, and I would not claim that many of them will ever be considered great works of literary art. However, applying to them a New Critical standard, which claims that a good literary work must stand on its own, apart from other texts and above history, as well as convey a vision that is ironic, ambiguous, and deeply layered, will also obscure their real worth as cultural documents. Few other types of literature are as capable of conveying the values or the rhetorical style of that generation during that period. And perhaps more than any other kind of art, such autobiographies tell us how that generation thought about itself while it was coming of age. The lack of apparent complexity in individual texts is at least partially made up for when they are read together, not only as a chorus of competing voices, but also as a sequence of voices, each one of which contributes to a narrative tracing the development of the generation's self-consciousness. Although space does not allow me to reconstruct this narrative or to characterize each of these voices, I can examine one text from this group, relate it to Cowley's book, and show those features that it has in common with other texts from its own historical period.

Michael Rossman (Figure 2) was an apologist for and historian of "the Movement" (a term denoting a wide range of left-wing political and counterculture groups in the late 1960s; anyone who professed sympathy for leftist ideals could claim to be "in" the Movement). He is not as well known nationally as some of his peers, such as Tom Hayden, Abbie Hoffman, and Jerry Rubin, but he was conspicuous within the Movement and on the West Coast, where he still lives. Born in 1939, Rossman was slightly older than many other generational autobiographers of the 1960 s and 1970s. He was also a "red-diaper baby" (the child of parents who were active leftists during the 1930s), and so grew up in a politically charged atmosphere. That background led him to an early interest in radical protest, and he joined others to demonstrate against the witch-hunting activities of the House Un-American Activities Committee in 1960. Rossman was a prolific writer of political/cultural commentary throughout the 1960 s for a wide variety of journals, both mainstream and underground. His three books, The Wedding Within the War (1971), On Learn- 


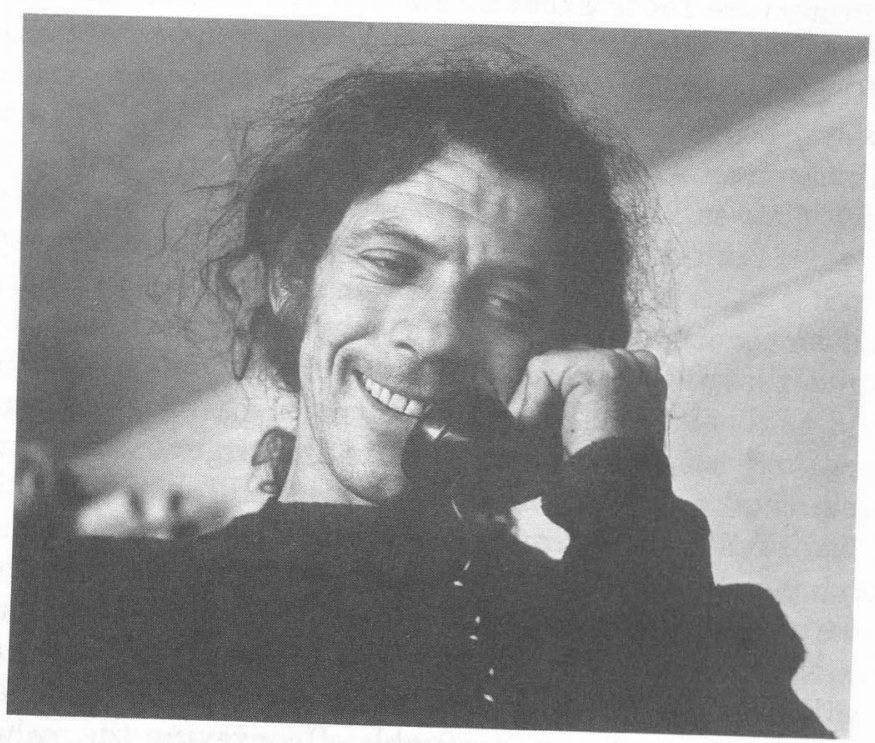

Figure 2. Michael Rossman in 1971, about the time that The Wedding Within the
War was published.

ing and Social Change (1972), and New Age Blues: On the Politics of Consciousness (1979), ${ }^{20}$ are all concerned with personal witness and historical change, leftist politics, educational reform, and the human potential movement. As a veteran of the 1960 s, he continues to write about the issues that informed that era.

The Wedding Within the War may not have the historical depth of Cowley's autobiography, and Rossman shares with many of his contemporaries a brashness that is sometimes off-putting. But, in spite of these shortcomings, Rossman's book has much in common with Cowley's and offers further evidence of a tradition of collective autobiography. In addition, it provides an excellent introduction to the themes important to this generation of autobiographers, including its concern with change as an element of generational identity, its emphasis on the autobiographer's prophetic role, and its explicit use of autobiography as an instrument of

At the book's center is an experience that paralleled Cowley's account of his generation's collective conversion to Marxism. For Rossman, the most important event in the coming of age of his generation was the emergence of a counterculture in the mid-1960s. That culture offered, he thought, a new model of identity for a collective self that would merge with and transmute the political identity already established for the generation by New Left manifestos such as the Students for a Democratic largely by The Port Huron Statement (1962). The SDS manifesto, written largely by Tom Hayden, begins with a brief, but paradigmatic collective 
autobiography describing the conditions of social/political life that have determined generational identity (the cold war, the nuclear arms race, automation, class differences, racism, etc.) and then goes on to outline an issue-oriented program of political reform for the generation. ${ }^{21}$ The counterculture, on the other hand, offered in generational works such as Raymond Mungo's Total Loss Farm an identity that called for a radical change of consciousness, with an emphasis on communalism, alternative life styles, altered (drug-induced) realities, new-age therapies, and sexual liberation; it was utopian, mythic, and visionary, where the New Left was socialist, historical, and pragmatic. ${ }^{22}$ Rossman imagined a merging of these two identities, and during the Free Speech Movement (FSM) at Berkeley, he thought he saw this merging beginning to take place; for Rossman, FSM constituted a generational conversion experience.

Despite Rossman's sympathy for Cowley's Marxism, there are differences between their conversions and their texts. Cowley's fits the conventional Christian paradigm provided by St. Paul's account of his dramatic conversion on the road to Damascus in the ninth chapter of the book of Acts. Both Paul's and Cowley's preconversion identities completely fall away as they assume their postconversion identities, and it is from the point of view of these reborn identities that both of their narratives are told. Paul's conversion from persecutor of Christians to apostle of Jesus Christ is more than a simple change of vocation; the Christian convert, he claims in his letter to the Romans (chapters 5-8), is like Christ: the old self of fleshly desires has been crucified; the new self, resurrected like Christ, is governed by the spirit of holiness. While Rossman's FSM experience was somewhat analogous to Paul's blinding "light from heaven" and Cowley's historical cataclysm in 1929 (Rossman refers to FSM as "a heavy turning, a re-beginning. ... . an historical thunderbolt" [p. 92]), the conversion itself is to a process of becoming rather than to a wholly new self. For Rossman, FSM provided not so much a new self as a new means for constructing identity in the face of massive cultural dislocation. What Rossman found during FSM was not a new political or religious outlook, but a new understanding of his generation's potential for self-invention and growth. As a result, the primary model behind Rossman's understanding of collective identity, as he makes clear in On Learning and Social Change, is "radical" education rather than religious or quasi-religious belief. ${ }^{23} \mathrm{His}$ concept of generational identity therefore places more emphasis on change as a central feature of the generational self than does Cowley's.

To underscore this feature of generational identity, Rossman employs two techniques - one structural, the other verbal. Structurally, The Wedding Within the War is not simply a retrospective account of a conversion a là St. Paul, but an attempt to represent the various stages of the conversion from the point of view of the collective at significant points in the process. By arranging chronologically a collection of his essays, letters, poetry, and transcribed tape recordings written between 1959 and 1970, 
Rossman hoped to provide "not a history of what came to be called the Movement, but a series of views from its perspective - windows into time, key moments as they seemed at the time to one young man growing up through them" (pp. 3-4). Between each selection, Rossman has included short retrospective analyses that place the selections in historical context and reveal his present (1971) perspective on them. His intention in "building" an autobiography from earlier essays is to provide a narrative of the most important events in the generation's past, but to do so in a way that reveals, without retrospective mediation, the "limited consciousness" of the generational self as it was in the process of development.

Verbally, Rossman emphasizes the dynamic quality of the collective identity by transforming several of the catch phrases of his generational moment into metaphors for generational identity. For example, the various events that make up the narrative blocks of the autobiography are all "demonstrations." On one level, this term retains its usual reference to the political demonstrations that were so vital a part of this peer group's political style. For Rossman, however, the term denotes something more than protests against government policy; these public occasions are also opportunities for the young generation to demonstrate itself, to announce its changing identity. Rossman calls them "our public theater... in which we came together to show ourselves to each other and the world" (p. 4). This collective autobiography is also, then, an attempt to represent the changes that took place in the style of these "demonstrations" in order to show how the generation's collective identity developed over the course of the decade. ${ }^{24}$ The same thing may be said of his use of the phrase "the Movement." In usual parlance, this term referred to the broadly based groups that opposed American policy in Vietnam, or the denial of civil rights to oppressed groups, or the culture created by consumer capitalism. In Rossman's usage, however, the term is much more literal: it denotes the central feature of the generation's attempts to define itself. "Always," he says, "the Movement was a process of redefining ourselves" (p. 77). And later, he adds that "the Movement is a process of growth: for groups no less than individuals, a fixed identity is a death" (p. 150).

The book's plot therefore traces the "movement" of these "demonstrations," and ties them together. It begins with accounts of old-left style demonstrations against capital punishment and the House Un-American Activities Committee in 1960. The public identity that these demonstrations evinced is brought to an abrupt and dramatic turn during the spontaneous 1964 FSM uprising with its radically democratic forms. Unlike the old-left demonstrations, which grew out of the careful planning of an ideologically oriented cadre of socialists, the FSM was a spontaneous expression of popular dissent. It was characterized by collective discussions in which hundreds of people, not simply an elite cadre, took part. The rest of the book records the way in which the collective self that emerged from the FSM "conversion" eventually expressed itself in the frustrated rage and violent confrontations that marked the Democratic 
National Convention in 1968, the People's Park protests in Berkeley in 1969 , and the rise of the free school and educational reform movements in the late 1960s. The final chapters of the book are marked by two developments: an increasingly apocalyptic rhetoric, as the young generation, in Rossman's view, readies itself for an inevitable civil war with official "Amerika," and a coming-together of the young culture's identity, which Rossman celebrates in his accounts of his counterculture marriage to Karen McLellan in 1969 and his announced intentions concerning the education of their son, Lorca.

Consonant with his greater emphasis on change as an element of collective identity, Rossman also places greater stress on another element of Cowley's work: the collective autobiographer as prophet. Given Cowley's Marxism, his predictions about the direction of history are to be expected. He reserved these predictions, however, for the final chapter of his work. In Rossman's book, prophetic concerns dominate the entire narrative and are intimately related to his notion of his own role within the generation. Unlike Ortega's belief that an intellectual elite heralds and conducts the generation's historical tasks or Cowley's notion that artists provide a sensitive barometer of the generational spirit, Rossman and other 1960s generationalists subscribed to a belief in what I term "geographical elitism" - a conviction that the behavior of young people in a particular geographical location foreshadows the direction of history. This was, in fact, one of the many meanings of the common 1960s question, "Where's it happening, man?" Colloquially, the "it" in this phrase simply meant "fun" or "good times." For serious Movement members like Rossman, however, the "it" clearly refers to "the cutting edge of history." One manifestation of the breakup of the Movement after 1968 was the internecine argument over where "it was happening." Raymond Mungo and the counterculture "communards" thought it was happening in places such as Vermont, Taos, Mendocino, and British Columbia where a withdrawal from leftist politics and a back-to-the-land movement was taking place. ${ }^{25}$ More politically minded generationalists continued to believe that it was only happening in major urban centers. Rossman held up the special virtues of Berkeley, which he called, in a phrase recalling Cowley's artists, "Barometer City." Berkeley was a kind of middle ground, neither too urban nor too rural; it was known both for its radical politics and its alternative life styles. "The wavelengths of our common transformations flow strongly through Berkeley," Rossman claimed: "For twelve years now what happens here and across the Bay happens a year or two late in concentric circles spreading out across Amerika" (p. 12). One function to serve as "an tional prophet, therefore, was to remain in such " and to hang "on the tip of the rushing wave" (p. 12).

One of Rossman's intentions in The Wedding is to establish his credentials as prophet from the city where all those who "stay open and are transmuted" (p. 12) are, by dint of geographical accident, gifted with 
foresight. Given that intention, his "windows-into-time" approach to autobiography provides a form that allows him to make the strongest case for his prophetic powers. Because his readers can see the actual texts of the predictions that he was making in 1963, they can form their own judgment about his prescience and his suitability as a leader who could formulate the identity adaptations that the generation would have to make to accommodate historical change.

It would be unfair, however, to say that Rossman chose his "windowsinto-time" form only with the intention of establishing his identity as a seer. More important to Rossman was his sense of the genre's potential as an instrument of identity politics. Consequently, the primary motivation for choosing a "windows-into-time" form was that it was the most appropriate way of conveying a story of the generation's past that would empower that generation and enlighten it politically. ${ }^{26}$ Addressing the younger members of the generation in his opening comments, Rossman explained:

[T]hese tales are scraps of our common history. You will recognize their experience, archaic as some of its aspects may seem. You are not alone, least of all in Time. You share a heritage of developing struggle which stretches back continuously through these events, and through earlier roots we have all but forgotten - we who were born in the landscape the glaciers scoured clean. (pp. 31-32)

The form Rossman chose was one that he believed would effectively provide the developing generation with a sense of its political identity. And the characteristic of that identity that most concerned Rossman was its ability to adapt to the changing conditions of history. His book, Rossman claimed, was "not so much [a history] of events as of the perceptions and consciousness that attended them" (p. 77).27 In order to convey this history of generational consciousness, Rossman,
like Cowley, uses himself as a representative figure whose consciousness stands in for the collective consciousness: "My accounts are typical," Rossman claims, "of the consciousness of the white Movement at the time" (p. 31). Acording to both of these writers, one is typical if one is present at the great, symbolic rites of one's times (for Rossman, such events included the FSM or the 1968 Chicago Convention), but one could become representative by assuming a "voice," by explaining to members of the generation what their "demonstration" had, in fact, demonstrated about them and their world. Rossman's generational autobiography adopts the "we" from this position. He saw himself as someone who was (as he said of Jerry Rubin) "helping to articulate a myth of central significance to us" (p. 267). That myth was meant not only to capture the emerging political identity of
the young, but also to construct and direct it.

Of course, just as Cowley's generational collective had its base first of all in his own experience, and then in the literary coterie to which he 
belonged, Rossman's generational identity begins with himself and other members of the Movement. And just as Cowley's literary generation comes to stand in for the entire generation, so Rossman's political "we" frequently stands in for a larger generational "we." According to Rossman's account, "the Movement itself had become a presence, forcing all the young to begin in some way to define themselves with respect to it" ( $p$. 76). Even for those members of the generation who disagreed with the politics of the Movement, the central issues of identity raised by its spokespersons remained the issues against which everyone had to define themselves. That Rossman was not alone in this sort of generational thinking is clear from the many others who echoed his sentiments. In the same year that Rossman published his autobiography, Jerry Rubin wrote in We Are Everywhere, "No individual can escape the mood of his or her generation. We live in one of those periods of history, including rapid change, where the history of the movement is the history of each individual" (p. 98).

Naturally, this projection of the individual self onto the collective self created differences between the generational autobiographers of this period, all of whom may be said, from one point of view, to be writing the same collective work. Reading Rossman in the context of other generational autobiographies of his era, one becomes aware of both an intragenerational and an intergenerational dialogue about the collective identity of the young. ${ }^{28}$ Sometimes this dialogue is explicit; frequently, however, the other voices involved in the dialogue (a former self, parents, peers, political foes, the other gender, other races, other classes, etc.) are only implicit, but their covert presence heavily shapes the meanings of the narratives. Although the various autobiographers agreed that a "we" existed, they disagreed over the precise nature of that "we," over which events in "our" past constituted major turning points, and, after 1968, over "our" future.

In Rossman's book, the intragenerational dialogue is explicit in an open letter to Jerry Rubin in which Rossman argues with Rubin over the way in which the "mythic unconsciousness of the young" (p. 263) ought to be addressed before the upcoming (August, 1968) demonstration at the Democratic Convention in Chicago. Taking issue with Rubin's plan to attract large numbers of youth to Chicago with promises of a rock festival and peaceful street demonstrations, Rossman warns of a bloodbath and says that the organizers should instead "help people see clearly all that is of importance to them" (p. 264), including the possibility of a violent confrontation with police. Ultimately, Rossman's argument with Rubin's yippie style here, and with leftist politics in other places, is that in formulating generational identity and imperatives, both are "seeking too easy an alternative. The joy [of yippie] and the politics [of the New Left] must be fused, as they began to be in FSM" (p. 269). The intergenerational dialogue, on the other hand, can be seen in the chapter "Barefoot in a Marshmallow World," in which Rossman responds to the older genera- 
tion's efforts to explain FSM. Summing up several books of analyses on the subject, Rossman says that "plowing through this telephone book" of data, "one doesn't notice that the face above it is featureless: there's no sense of identity.... [H] undreds of articles have been written on and around FSM, but only a bare handful by us. Everyone's quick to speak for us, but no one asks us to speak" (p. 127). In response, Rossman offers this essay as an attempt to formulate that identity from the point of view of an
active participant.

What emerges from these dialogues is a sense of this generation's conviction that identity and politics are inextricably connected and the corollary belief that autobiography, because of its concern with identity, is always an essentially political act. ${ }^{29}$ For this reason, it is not surprising that Rossman's work ends with a chapter that resembles a political manifesto. Like Cowley, Rossman constructs a collective identity with an explicit political agenda, and both authors view the autobiographer's narration of a collective past principally as a means of directing the future political behavior of the collective. Cowley's book ends with a section entitled "Yesterday and Tomorrow," in which he calls upon his artistic peers to abandon their natural class affiliation in order to join the proletariat in bringing about a workers' revolution. Rossman's ends with a section entitled "Toward the Future," in which he announces the secession of youth from the State, declares their "independence from its essential instrument, the System of Education," calls upon the young "to come together, to share their powers in critical mass and intimacy," and advises them that they must prepare "to fight for the cradle of the future"
(pp. 395-97).

$* * *$

The question remains how collective autobiography comes to be written in a culture dominated by the ideology of individualism. During the 1930 s and the 1960s, at least two factors appear to have been at work one of them ideological, the other cultural. Both of our writers subscribed to historicist ideologies that ran counter to the hegemonic ideology of individualism. Those ideologies - Marxism, generationalism, and identity politics - provided autobiographers with concepts of collective identity. In Exile's Return, the Marxist framework dominated. In The Wedding, a dynamic generationalism and identity politics played the larger role. Both autobiographers were also writing during periods of cultural upheaval when their perception of their generation's history was aligned with what they took to be the direction of History. The historicist ideologies provided by Marxism and generationalism were corroborated, during the $1930 \mathrm{~s}$, by the apparent success of the Soviet collectivist state together with the apparent collapse of consumer capitalism. They were again cor- 
roborated, during the $1960 \mathrm{~s}$, by the appearance of a youth movement of unprecedented size that engaged in mass protests against racism, the Vietnam War, and the affluent culture of the older generation. The coincidence of these cultural situations and collectivist ideologies provided the context within which generational autobiographies were possible.

\section{NOTES}

I would like to thank Oscar Kenshur, Carl Malmgren, John Cooke, John Gery, and Rick Barton for their helpful comments on early drafts of this essay.

1. Exile's Return: A Literary Odyssey of the 1920s (New York: Viking, 1956), p. 10. The 1934 edition (New York: W. W. Norton) was entitled Exile's Return: A Narrative of Ideas.

2. For a discussion of these revisions, see John D. Hazlett, "Conversion, Revisionism, and Revision in Malcolm Cowley's Exile's Return," South Atlantic Quarterly 82 (1983): 179-88.

3. Gusdorf's essay was originally published in Formen der Selbstdarstellung: Analekten zu einer Geschichte des literarischen Selbstportraits, ed. Günther Reichenkron and Erich Haase (Duncker and Humblot, 1956). It has since been translated by James Olney as "Conditions and Limits of Autobiography," in Autobiography: Essays Theoretical and Critical, ed. J. Olney (Princeton, N.J.: Princeton University Press, 1980), pp. 28-48. One influential theorist following Gusdorf's lead is Karl J. Weintraub, The Value of the Individual: Self and Circumstance in Autobiography (Chicago: University of Chicago Press, 1978).

4. Post-structuralists and more traditional theorists of autobiography, while disagreeing over many aspects of the genre, hold in common the belief that the Romantic individual self is central to it. For a discussion of this issue from the post-structural point of view, see Candace Lang, "Autobiography in the Aftermath of Romanticism," Diacritics 12 (Winter 1982): 2-16. For the linkage between autobiography and capitalism, see Thomas Doherty, "American Autobiography and Ideology," in The American Autobiography: A Collection of Critical Essays, ed. Albert Stone (Englewood Cliffs, N.J.: Prentice Hall, 1981), pp. 95-108; Michael Ryan, "Self-Evidence," Diacritics 10 (1980): 2-16; and Robert Elbaz, The Changing Nature of the Self: A Critical Study of the Autobiographic Discourse (Iowa City: University of Iowa Press, 1987).

5. An example of the feminist response to theorists such as Gusdorf can be found in Susan Friedman, "Women's Autobiographical Selves: Theory and Practice," in The Private Self: Theory and Practice of Women's Autobiographical Writings, ed. Shari Benstock (Chapel Hill: University of North Carolina Press, 1988), pp. 34-35. For an essay that insists on a generic difference between "autobiography" and works that reconstruct a collective identity, see Doris Sommer, " Not Just a Personal Story': Women's Testimonios and the Plural Self, in Life/Lines: Theorizing Women's Autobiography, ed. Bella Brodski and Celos an example of aca, N.Y.: Cornell University Press, 1988), pp. Black Autobiography in AmerAfrican-American theory, see Steven Butterfield, Black

ica (Amherst: University of Massachusetts Press, 1974) other members of Cowley's

6. For a list of autobiographical work, in McAlmon and the Lost Generation: A peer group, see "Biographical Repertory, University of Nebraska Press, 1962), pp. Self Portrait, ed. Robert Kenerational theme is present in many of these memoirs.

7. Michael Rossman, The Wedding Within the War (New York: Doubleday, 
1971), p. 296. My reading of Cowley's book is based on the 1934 edition (New York: Norton). Subsequent references to these works will be given in parentheses
in the text.

8. For a complete discussion, see Robert Wohl, The Generation of 1914 (Cambridge: Harvard University Press, 1979); Julián Mariás, Generations: a Historical Method, trans. Harold C. Riley (Mobile: University of Alabama Press, 1970); Alan Spitzer, "The Historical Problem of Generations," American Historical Review 78 (1973): 1359-85; and Hans Jaeger, "Generations in History: Reflections on a Controversial Concept," History and Theory: Studies in the Philosophy of History

9. Wohl, Generation of 1914 , pp. 207-8.

10. Bourne's generational work is collected in Youth and Life (Cambridge, Mass.: Riverside, 1913). A semi-autobiographical essay by Bourne that might have served as a model for Exile's Return is "The History of a Literary Radical," in War and the Intellectuals: Collected Essays, 1915-1919, ed. Carl Resek (New York: Harper, 1964), pp. 184-97. José Ortega y Gasset's most important generational works were El tema de nuestro tiempo (1923) and En torno a Galileo (1933). Other important generational theorists in Europe during the decade immediately preceding Cowley's book include Wilhelm Pinder, Kunstgeschichte nach Generationen (1926), Edward Wechssler, Die Generationen als Jugendgemeinschaft (1927) and "Das Problem der Generationen in der Geistesgeschichte (1929), Karl Mannheim, "Das Problem der Generationen" (1928), and Julius Peterson, Die Literarischen
Generationen (1930).

11. See Bourne, Youth and Life, pp. 1-53, where this idea is elaborated.

12. This idea is echoed by almost all later generational writers. For example, Joyce Maynard (see note 18) writes in her generational autobiography that the world" (p. 13).

13. See especially Cowley, - And I Worked the Writer's Trade: Chapters of Literary History, 1918-1978 (New York: Viking, 1979), pp. 8-20.

14. José Ortega y Gasset, The Modern Theme, trans. James Cleugh (London: Daniels, 1931), p. 15. This work was first published in America in 1933 by the
same publisher who, one year later, published Cowley's book.

15. Compare, for example, Cowley's description of his college experience on $\mathrm{p}$. 35 with Veblen's “The Higher Education" in The Theory of the Leisure Class (New York: Modern Library, 1934), p. 395; with Van Wyck Brooks on American education in America's Coming of Age (New York: Dutton, 1915), p. 12; or with

Bourne's account in "The History of a Literary Radical," pp. 185-86.
16. Exile's Return (1956), p. 11. Cowley's claim in the revised edition that "he
had failed to show [the Crosby chapter's] had failed to show [the Crosby chapter's] connection with the rest of the [1934] central elements of the Marxist conversion narrative, damaged the narrative pounded by his treatment account of Crosby's suicide. This damage was comedition, every character was new "characters" in the revised version. In the 1934 and plot. In the 1951 revis shown in relation to a single generational identity Dos Passos, and Hart Crane, but he failses new sections on Pound, Cummings, generational plot, and his treatment of them is their relation to the original One explanation for this change is that the is consequently merely anecdotal. who did not conform to the narre 1934 Cowley ignored those writers would insure a place within the did not return, and he certainly did for his friends. Pound was an exile, but he "premature" Marxist in the 1920s, and his politics Marxism. Dos Passos was a after he returned from exile. But the 1951 politics became more conservative position: no longer an outsider struggling for admiey was in a different political 
was himself an ex-Marxist member of an elite that guarded the canon. Now that his own group of writers was firmly in place, he could afford to recognize those other white, male authors who had succeeded in gaining admission by some other door.

17. This generation's well-known rebellion against rigid sexual codes rarely manifested itself in self-conscious political stances. For the best study of attitudes among the young during the $1920 \mathrm{~s}$, see Paula S. Fass, The Damned and the Beautiful: American Youth in the 1920's (New York: Oxford University Press, 1977).

18. Works that attempt to define a collective self include Abbie Hoffman, Revolution for the Hell of It (New York: Dial, 1968); James Simon Kunen, The Strawberry Statement: Notes of a College Revolutionary (New York: Avon, 1969); Dotson Rader, $i$ ain't marchin' anymore (New York: David McKay, 1969); Raymond Mungo, Famous Long Ago: My Life and Hard Times with Liberation News Service (Boston: Beacon, 1970) and Total Loss Farm: A Year in the Life (New York: Dutton, 1970); Jerry Rubin, Do It! Scenarios for the Revolution (New York: Simon and Schuster, 1970); Stephen Diamond, What the Trees Said: Life on a New Age Farm (New York: Delacorte, 1971); Michael Rossman, The Wedding Within the War (New York: Doubleday, 1971); Jerry Rubin, We Are Everywhere (New York: Harper and Row, 1971); Joyce Maynard, Looking Back: A Chronicle of Growing Up Old in the Sixties (New York: Avon, 1972); Dotson Rader, Blood Dues (New York: Knopf, 1973); Jonah Raskin, Out of the Whale: Growing Up in the American Left (New York: Links, 1974); Jerry Rubin, Growing (Up) at 37 (New York: M. Evans, 1976); Michael Rossman, New Age Blues: On the Politics of Consciousness (New York: Dutton, 1979); Patricia Hampl, A Romantic Education (Boston: Houghton Mifflin, 1981); and David Harris, Dreams Die Hard: Three Men's Journey Through the Sixties (New York: St. Martin's/Marek, 1982). Subsequent references to these works will be to these editions.

19. For discussion of the concept of "identity politics," see Linda Alcoff, "Cultural Feminism Versus Post-Structuralism: The Identity Crisis in Feminist Theory," Signs 13, no. 3 (Spring 1988): 282-88; and Elly Bulkin, Minnie Bruce Pratt, and Barbara Smith, Yours in Struggle: Three Feminist Perspectives on Anti-Semitism and Racism (Brooklyn: Long Haul Press, 1984).

20. Michael Rossman, On Learning and Social Change (New York: Random House) and New Age Blues: On the Politics of Consciousness (New York: Dutton).

21. The Statement's approach caused a rift with SDS's parent organization, the League for Industrial Democracy (LID), which represented an older generation of leftists. The best general discussion of this break can be found in James Miller, "Democracy Is in the Streets": From Port Huron to the Siege of Chicago (New York: Simon and Schuster, 1987). Miller's book also contains the complete text of The Port Huron Statement in an appendix (pp. 329-74). For the LID point of view, see Michael Harrington, Fragments of a Century: A Social Autobiography (New York: Dutton, 1973), pp. 132-65. For the SDS point of view, see Tom Hayden, Reunion: A Memoir (New York: Random, 1988), pp. 73-102.

22. Two contemporary analyses of the counterculture are Keith Melville's Communes in the Counter Culture: Origins, Theories, Styles of Life (New York: Morrow, 1972) and Theodore Roszak's The Making of a Counter Culture: Reflections on the Technocratic Society and Its Youthful Opposition (New York: Doubleday, 1968).

23. I am unable to do justice to Rossman's notions about education here. For his understanding of the relationship between collective identity and cultural change and education, see On Learning and Social Change, pp. 45-50, 69-79.

24. The notion of collective identity as "public theater" may also be found in Cowley's book. See the section "Significant Gesture" (pp. 173-80) that relates a "demonstration" in which Cowley publicly punches a cafe proprietor. 
25. For Mungo's view of this, see Mungo, Total Loss Farm, p. 98.

26. Not all of Rossman's generationalist contemporaries used the genre for these ends. Dotson Rader viewed his $i$ ain't marchin' anymore and Blood Dues as plain to himerapeutic tools. By examining his own psyche, he attempts to exMungo saw his weneration. And Raymond generational of history in which the world

27. Rossman's thapped.

provided his readers in Exilention here is remarkably like the one that Cowley record of events as a narrative seturn: "I want to write what is not so much a ones that half-unconsciously guideas. . . The ideas that concern me here are the wrote by" (pp. 12-13).

28. This dialogical feature can also be found in Cowley's book, particularly in the section "The Other Side of the Tracks," in which Cowley engages in arly in tragenerational argument with a socialist worker, tional identity.

29. Critics such as Christopher Lasch, who complain that this generation sought to establish its identity through political activism rather than submerge its identity in a larger cause, ignore the sociopsychological effects of oppression on marginalized groups as well as the role of identity politics in power relations between groups. For marginalized groups, the struggle for power is precisely the struggle to create one's own identity: when one has the power to say who one is, one has gone a long way toward gaining the kind of recognition that leads to economic and social power. See Lasch, The Culture of Narcissism: American Life in an Age of Diminishing Expectations (New York: Warner, 1979), pp. 27-48. 